\title{
Weed Infestation and Yielding of Potato Under Conditions of Varied Use of Herbicides and Bio-Stimulants
}

\author{
Marek Gugała', Krystyna Zarzecka' ${ }^{1}$ Honorata Dołęga ${ }^{2}$, Anna Sikorska ${ }^{3 *}$ \\ 1 Department of Agrotechnology, Faculty of Natural Sciences, Siedlce University of Natural Sciences and \\ Humanities, B. Prusa 14, 08-110 Siedlce, Poland \\ 2 Undertaking Trade "Soleks" Wojnów, Poland \\ 3 Department of Agriculture, The State Higher School of Vocational Education in Ciechanów, Narutowicza 9, \\ 06-400 Ciechanów, Poland \\ * Corresponding author's e-mail: anna.sikorska@pwszciechanow.edu.pl
}

\begin{abstract}
The aim of the study was to determine the effect of applied herbicides and growth regulators on the airborne limitation of dry weed mass and the total yield of three edible potato varieties. The field experiment was established as two-factor in a (split-plot) system in three replications. The experiment examined: I factor - three moderately early varieties of edible potato: Bartek, Gawin, Honorata. II factor - five ways of using herbicides and bio-stimulants: 1. control object: mechanical care 2. Harrier $295 \mathrm{ZC}$ herbicide at a dose of $2.0 \mathrm{dm}^{3} \cdot \mathrm{ha}^{-1}, 3$. Harrier $295 \mathrm{ZC}$ herbicide at a dose of $2.0 \mathrm{dm}^{3} \cdot \mathrm{ha}^{-1}$ and then after the plant rises the Kelpak SL bioregulator twice at a dose of $2.0 \mathrm{dm}^{3} \cdot \mathrm{ha}^{-1}$, 4. Sencor $70 \mathrm{WG}$ herbicide at a dose of $1.0 \mathrm{~kg} \cdot \mathrm{ha}^{-1}, 5$. Sencor $70 \mathrm{WG}$ herbicide and then after the plant rises the Asahi SL bio-stimulant twice at a dose of $1.0 \mathrm{dm}^{3} \cdot \mathrm{ha}^{-1}$. The obtained test results showed that the smallest dry weed mass determined in both research dates was obtained using Harrier 295 ZC herbicide and Kelpak SL growth biostimulant $\left(0.7 \mathrm{~g} \cdot \mathrm{m}^{-2}\right.$ and $\left.3.1 \mathrm{~g} \cdot \mathrm{m}^{-2}\right)$, while the largest in the control object $\left(15.1\right.$ and $\left.64.7 \mathrm{~g} \cdot \mathrm{m}^{-2}\right)$, respectively. The total yield of potato tubers depended on both the types of herbicides and bio-stimulants used and the varieties cultivated in the experiment. However, the weather conditions which varied in particular years significantly influenced both the size of the air-dried mass of weeds and the total yield of potato tubers.
\end{abstract}

Keywords: air-dry weed mass, herbicides, bio-stimulants, total yield

\section{INTRODUCTION}

According to Anioł et al. [2008] and Matysiak [2010], the difference between the potential yield of current crop varieties (obtained under optimal growth conditions) and the actual yield obtained by the farmer (reduced by diseases, pests and weeds and stress abiotic factors) can be as high as $70 \%$.

At a global scale, among all pests, weeds have the greatest impact on the yield reduction, with an average of $34 \%$. In addition, as an intermediate host, they can be a source of diseases and pests, and secondary weed infestation can greatly limit the proper collection of tubers [Fernandez-Quintanilla et al. 2008, Praczyk and Skrzypczak 2011].
Therefore, an appropriate selection of varieties and herbicides and their proper use, allows to achieve a yield increase at a satisfactory level [Sawicka et al. 2011, Zarzecka et al. 2013, Gugała et al. 2014].

In addition, in recent years, next to industrial means of production, such as pesticides, preparations qualified as plant development regulators or bio-stimulants [Maciejewski et al. 2007], algal extracts [Dobrzański et al. 2008], bacterial vaccines [Emitazi et al. 2004] or immune stimulants [Koziara et al. 2006] have been used increasingly often.

The aim of the study was to determine the effect of the applied herbicides and growth regulators on the limitation of air-dried weed mass and the total yield of three edible potato varieties. 


\section{MATERIAL AND METHODS}

The research results were obtained from the experiment carried out in the years 2012-2014. The field experiment was established as two-factor in the (split-plot) system in three replications. The experiment tested the following:

I factor: varieties of edible potatoes: Bartek, Gawin, Honorata.

II factor: ways of using herbicides and bio-stimulants:

1. control object: mechanical care prior to and after the emergence of potato plants, i.e. ridging twice and ridging with harrowing once until the emergence, and the two-fold ridging, without harrowing, after the emergence.

2. mechanical-chemical care, i.e. mechanical and chemical care, i.e. ridging once until the emergence, and about 7-10 days after planting tubers, application of Harrier 295 ZC herbicide at a dose of $2.0 \mathrm{dm}^{3} \cdot \mathrm{ha}^{-1}$,

3. mechanical-chemical care, i.e. ridging once until the emergence, and about 7-10 days after planting tubers, application of Harrier 295 $\mathrm{ZC}$ herbicide at a dose of $2.0 \mathrm{dm}^{3} \cdot \mathrm{ha}^{-1}$, then at the end of emergence of potato plants, addition of the Kelpak SL bioregulator at a dose of $2.0 \mathrm{dm}^{3} \cdot \mathrm{ha}^{-1}$ and then 14-28 days after the first treatment, the addition of Kelpak SL bioregulator at a dose of $2.0 \mathrm{dm}^{3} \cdot \mathrm{ha}^{-1}$,

4. mechanical-chemical care, i.e. ridging twice and ridging with harrowing once until the emergence, and application of the Sencor 70 WG herbicide at a dose of $1.0 \mathrm{~kg} \cdot \mathrm{ha}^{-1}$ just before the emergence,

5. mechanical-chemical care, i.e. ridging twice and ridging with harrowing once before the emergence, and addition of the Sencor $70 \mathrm{WG}$ herbicide at a dose of $1.0 \mathrm{~kg} \cdot \mathrm{ha}^{-1}$ just before the emergence, then at the end of the emergence of potato plants, application of the Asahi SL bio-stimulant at a dose of $1.0 \mathrm{dm}^{3} \cdot \mathrm{ha}^{-1}$ and then 14-28 days after the first treatment addition of the Asahi SL bioregulator at a dose of $1.0 \mathrm{dm}^{3} \cdot \mathrm{ha}^{-1}$.

The analysis of weed infestation was done using the quantitative weight method on two dates: 2-3 weeks after the application of herbicides (before reducing the row density) and at the end of potato vegetation (1-2 weeks before harvesting tubers). The observations were carried out on a surface of $0.5 \mathrm{~m}^{-2}$ determined by a frame measuring $33.4 \times 150 \mathrm{~cm}$. The frame was randomly thrown into three places on each plot, diagonally through the ridges. The total potato tuber yield was calculated on the basis of the mass of tubers collected from the surface of one plot, and then converted into $\mathrm{t} \cdot \mathrm{ha}^{-1}$.

The research results were statistically analyzed using the analysis of variance. The significance of the sources of variability was tested with the "F" Fischer-Snedecor test, and the assessment of the significance of differences was conducted at the significance level $\mathrm{p}=0.05$ between the compared averages, using the multiple intervals of Tukey [Trętowski and Wójcik 1991].

The weather conditions in individual growing seasons of vegetation were varied (Table 1). The smallest rainfall amounting to $264.9 \mathrm{~mm}$ was recorded in 2012, which was characterized by the highest average air temperature of $15.4^{\circ} \mathrm{C}$. However, the largest rainfall (on average $-441.3 \mathrm{~mm}$ ) was recorded in the 2013 vegetation season with an average air temperature of $15.0^{\circ} \mathrm{C}$. The growing season in 2014 was characterized by the sum of precipitation at the level of $335.1 \mathrm{~mm}$ and air temperature of $15.3{ }^{\circ} \mathrm{C}$.

Table 1. Characteristic of weather conditions in the years 2012-2014

\begin{tabular}{|c|c|c|c|c|c|c|c|}
\hline \multirow{2}{*}{ Yers } & \multicolumn{7}{|c|}{ Month } \\
\hline & IV & $\mathrm{V}$ & VI & VII & VIII & IX & IV - IX \\
\hline \multicolumn{7}{|c|}{ Rainfalls (mm) } & Sum \\
\hline $\begin{array}{l}2012 \\
2013 \\
2014\end{array}$ & $\begin{array}{l}29.9 \\
36.0 \\
45.0\end{array}$ & $\begin{array}{c}53.4 \\
105.9 \\
92.7\end{array}$ & $\begin{array}{l}76.2 \\
98.8 \\
55.4\end{array}$ & $\begin{array}{l}43.0 \\
91.3 \\
10.0\end{array}$ & $\begin{array}{c}51.0 \\
15.0 \\
105.7\end{array}$ & $\begin{array}{l}11.4 \\
94.3 \\
26.3\end{array}$ & $\begin{array}{l}264.9 \\
441.3 \\
335.1\end{array}$ \\
\hline $\begin{array}{c}\text { Multiyear sum } \\
(1987-2000)\end{array}$ & 38.6 & 44.1 & 52.4 & 49.0 & 43.0 & 47.7 & 275.2 \\
\hline \multicolumn{7}{|c|}{ Air temperature $\left({ }^{\circ} \mathrm{C}\right)$} & Mean \\
\hline $\begin{array}{l}2012 \\
2013 \\
2014\end{array}$ & $\begin{array}{l}8.9 \\
7.4 \\
9.8 \\
\end{array}$ & $\begin{array}{l}14.6 \\
15.3 \\
13.5\end{array}$ & $\begin{array}{l}16.3 \\
18.0 \\
15.4\end{array}$ & $\begin{array}{l}20.7 \\
19.0 \\
20.8\end{array}$ & $\begin{array}{l}18.0 \\
18.8 \\
18.1\end{array}$ & $\begin{array}{l}14.1 \\
11.7 \\
14.1\end{array}$ & $\begin{array}{l}15.4 \\
15.0 \\
15.3\end{array}$ \\
\hline $\begin{array}{c}\text { Multiyear mean } \\
(1987-2000)\end{array}$ & 7.8 & 12.5 & 17.2 & 19.2 & 18.5 & 13.1 & 14.7 \\
\hline
\end{tabular}




\section{RESULTS AND DISCUSSION}

The statistical calculations have proven a significant influence of the weather conditions prevailing in particular years of research, varieties grown in the experiment and the methods of care applied to the value of dry weed matter determined in two research dates (Tables 2, 3).

The course of atmospheric conditions in subsequent years of research had a significant impact on the value of the examined feature. The smallest weed infestation before reducing the row density and before harvesting potato tubers was obtained in 2014 (on average $-1.3 \mathrm{~g} \cdot \mathrm{m}^{-2}$ and $19.2 \mathrm{~g} \cdot \mathrm{m}^{-2}$ ). A significant influence of the atmospheric conditions on the level of weed infestation is also reported by Sekutowski and Badowski [2010], Gugała et al. [2014], Mystkowska et al. [2017] in their research.

The variance analysis showed that the level of weed infestation at the beginning of potato vegetation as well as before harvesting tubers differed depending on the varietal properties. The largest dry mass of weeds marked before reducing row density was recorded on the sites where the Honorata cultivar was grown - an average of $7.6 \mathrm{~g} \cdot \mathrm{m}^{-2}$, while before harvesting tubers with the Gawin cultivar - an average of $27.8 \mathrm{~g} \cdot \mathrm{m}^{-2}$ was achieved. The lowest value of this feature was obtained in the Bartek cultivar (in the first period $5.5 \mathrm{~g} \cdot \mathrm{m}^{-2}$ and in the second period 19.7 $\left.\mathrm{g} \cdot \mathrm{m}^{-2}\right)$. The obtained results of the authors' own research were confirmed by Sawicka et al. [2011] and the study by Mystkowska et al. [2017], who found that the most potent factor modifying the weed weight were the physiological and morphological properties of the studied varieties, such as: the sort of bushes, their height and foliage, above-the-ground mass of shrubs that effectively shadowed the inter-branches and the length of the growing season.

The best effects in limiting the dry weight of weeds, both before and after the harvest of potato tubers were obtained in the variant 3., where the Harrier 295 ZC herbicide was applied, and then the Kelpak SL biostimulator was added twice

Table 2. Air - dry weight of weeds $\left(\mathrm{g} \cdot \mathrm{m}^{-2}\right)$ (first date)

\begin{tabular}{|c|c|c|c|c|c|c|c|}
\hline \multirow{2}{*}{ Weed control methods } & \multicolumn{3}{|c|}{ Cultivars } & \multicolumn{3}{|c|}{ Years } & \multirow{2}{*}{ Mean } \\
\hline & Bartek & Gawin & Honorata & 2012 & 2013 & 2014 & \\
\hline 1. Control object & 12.2 & 14.2 & 18.7 & 6.0 & 32.6 & 6.6 & 15.1 \\
\hline 2.Harrier $295 \mathrm{ZC} 2.0 \mathrm{dm}^{3} \cdot \mathrm{ha}^{-1}$ & 0.7 & 0.7 & 2.1 & 3.4 & 0.0 & 0.0 & 1.1 \\
\hline $\begin{array}{l}\text { 3.Harrier } 295 \mathrm{ZC} 2.0 \mathrm{dm}^{3} \cdot \mathrm{ha}^{-1} ; 2 \text { x Kelpak } \\
\mathrm{SL} 2.0 \mathrm{dm}^{3} \cdot \mathrm{ha}^{-1}\end{array}$ & 0.4 & 0.6 & 1.2 & 2.2 & 0.0 & 0.0 & 0.7 \\
\hline 4.Sencor 70 WG $1.0 \mathrm{~kg} \cdot \mathrm{ha}^{-1}$ & 7.9 & 8.4 & 8.5 & 3.2 & 21.7 & 0.0 & 8.3 \\
\hline $\begin{array}{l}\text { 5.Sencor } 70 \text { WG } 1.0 \mathrm{~kg} \cdot \mathrm{ha}^{-1} ; 2 \text { x Asahi } \\
\text { SL } 1.0 \mathrm{dm}^{3} \cdot \mathrm{ha}^{-1}\end{array}$ & 6.1 & 7.0 & 7.3 & 1.6 & 18.9 & 0.0 & 6.8 \\
\hline Mean & 5.5 & 6.2 & 7.6 & 3.3 & 14.6 & 1.3 & - \\
\hline $\begin{array}{l}\mathrm{LSD}_{0.05} \text { for: } \\
\text { years } \\
\text { cultivars } \\
\text { weed control methods }\end{array}$ & & & & & & & $\begin{array}{l}2.1 \\
2.1 \\
2.2\end{array}$ \\
\hline
\end{tabular}

Table 3. Air - dry weight of weeds $\left(\mathrm{g} \cdot \mathrm{m}^{-2}\right)($ second date $)$

\begin{tabular}{|c|c|c|c|c|c|c|c|}
\hline \multirow{2}{*}{ Weed control methods } & \multicolumn{3}{|c|}{ Cultivars } & \multicolumn{3}{|c|}{ Years } & \multirow{2}{*}{ Mean } \\
\hline & Bartek & Gawin & Honorata & 2012 & 2013 & 2014 & \\
\hline 1. Control object & 63.2 & 71.6 & 59.2 & 65.8 & 68.5 & 59.7 & 64.7 \\
\hline 2.Harrier $295 \mathrm{ZC} 2.0 \mathrm{dm}^{3} \cdot \mathrm{ha}^{-1}$ & 5.2 & 16.8 & 14.5 & 33.2 & 3.3 & 0.0 & 12.2 \\
\hline $\begin{array}{l}\text { 3. Harrier } 295 \text { ZC } 2.0 \text { dm}^{3} \cdot \mathrm{ha}^{-1} ; 2 \text { x Kelpak } \\
\text { SL } 2.0 \mathrm{dm}^{3} \cdot \mathrm{ha}^{-1}\end{array}$ & 1.9 & 5.5 & 2.3 & 6.5 & 2.9 & 0.0 & 3.1 \\
\hline 4.Sencor 70 WG $1.0 \mathrm{~kg} \cdot \mathrm{ha}^{-1}$ & 14.4 & 28.7 & 19.7 & 19.8 & 23.2 & 19.8 & 20.9 \\
\hline $\begin{array}{l}\text { 5.Sencor } 70 \text { WG } 1.0 \mathrm{~kg} \cdot \mathrm{ha}^{-1} ; 2 \times \text { Asahi SL } \\
1.0 \mathrm{dm}^{3} \cdot \mathrm{ha}^{-1}\end{array}$ & 13.6 & 16.2 & 12.3 & 6.5 & 19.0 & 16.6 & 13.7 \\
\hline Mean & 19,7 & 27.8 & 21.6 & 26.3 & 23.4 & 19.2 & - \\
\hline $\begin{array}{l}\mathrm{LSD}_{0.05} \text { for: } \\
\text { years } \\
\text { cultivars } \\
\text { weed control methods }\end{array}$ & & & & & & & $\begin{array}{l}4.4 \\
4.4 \\
8.0\end{array}$ \\
\hline
\end{tabular}


at a dose of $2.0 \mathrm{dm}^{3} \cdot \mathrm{ha}^{-1}$. On this object, the dry mass of weeds before the reduction of row density was $0.7 \mathrm{~g} \cdot \mathrm{m}^{-2}$, and before the collection of tubers it equalled $3.1 \mathrm{~g} \cdot \mathrm{m}^{-2}$; In variant 2 ., where the Harrier 295 ZC herbicide was used, the value of dry mass was, respectively, 1.1 and $12.2 \mathrm{~g} \cdot \mathrm{m}^{-2}$. Moreover, the research shows that the Kelpak SL bio-stimulant used in the first study did not significantly the increase weed infestation or the biological activity of the herbicide, which was confirmed by the studies of Kositorna and Smoliński [2008] and Kierzek et al. [2013, 2015]. However, in the studies of Sawicka et al. [2011] conducted on the objects with Asahi SL bio-stimulant, higher values of both fresh and dry weight of weeds were observed, while the use of Insol 7 preparation, and its combined use with the Asahi biostimulant - reduced their weight. Furthermore, the results of studies by Golian et al. [2014] show that metribuzin used in the divided doses method, without stimulants and adjuvants, was more successful in destroying weeds (94.6\%), and the use of bio-stimulants and adjuvants separately or in combination with herbicides did not affect the efficacy of metribuzin.

According to many authors, Kołodziejczyk [2013], Gugała et al. [2014], Mystkowska et al. [2017], and the amount of rainfall during the growing season is the factor significantly limiting the potato yield. Statistical calculations showed a significant effect of weather conditions on the total yield of potato tubers. The highest value of the discussed feature - on average $47.29 \mathrm{t} \cdot \mathrm{ha}^{-1}$ was obtained in 2012, which was characterized by the lowest rainfall in the examined three-year period and the highest average air temperature. On the other hand, in 2013 and 2014, the total yield of potato tubers was at the same level and amounted to $36.82 \mathrm{t} \cdot \mathrm{ha}^{-1}$. The obtained results of the authors' own research proved that the use of growth bio-stimulants in the years with unfavourable weather conditions for potato growth and development may alleviate these effects by achieving the crop yield at an appropriate level, which was confirmed by research of Trawczyński [2014]. Obtaining a high yield of total potato tubers is possible owing to the use of chemical protection against weeds and the selection of varieties - Wichrowska [2008].

While analysing the cultivars studied in the experiment, it was found that the largest yield of potato tubers was obtained by cultivating the Honorata cultivar - an average of $42.29 \mathrm{t} \cdot \mathrm{ha}^{-1}$, while the smallest was achieved by cultivating the Gawin cultivar $-38.56 \mathrm{t} \cdot \mathrm{ha}^{-1}$. The obtained results were confirmed by the studies of Wierzbicka and Trawczyński [2016], who stated that the yields were significantly changed depending on the potato's early variety and the potato's use type.

The variance analysis showed that obtaining a high total yield was possible due to the application of comprehensive protection against weeds and the use of bio-stimulants. The highest total yield was at the level of $51.67 \mathrm{t} \cdot \mathrm{ha}^{-1}$ obtained on object 5., where the Sencor 70 WG herbicide was applied once and the Asahi SL bio-stimulant twice (Table 4). These results were confirmed by the studies of Trawczyński [2014], who proved that the application of Tecamin bio-stimulant under unfavourable weather conditions during the growing season, may alleviate certain stresses in potato plants and maintain a sufficiently high level of yield.

The studies by Maciejewski et al. [2008], Matysiak and Adamczewski [2010] show that after the application of Asahi SL and Atonik SL

Table 4. Total yield potato tubers in t.ha ${ }^{-1}$

\begin{tabular}{|c|c|c|c|c|c|c|c|}
\hline \multirow{2}{*}{ Weed control methods } & \multicolumn{3}{|c|}{ Cultivars } & \multicolumn{3}{|c|}{ Years } & \multirow{2}{*}{ Mean } \\
\hline & Bartek & Gawin & Honorata & 2012 & 2013 & 2014 & \\
\hline 1. Control object & 34.10 & 32.68 & 34.57 & 39.96 & 30.99 & 30.40 & 33.78 \\
\hline 2.Harrier $295 \mathrm{ZC} 2.0 \mathrm{dm}^{3} \cdot \mathrm{ha}^{-1}$ & 37.89 & 36.49 & 40.73 & 43.69 & 37.70 & 33.73 & 38.37 \\
\hline $\begin{array}{l}\text { 3. Harrier } 295 \mathrm{ZC} 2.0 \mathrm{dm}^{3} \cdot \mathrm{ha}^{-1} ; 2 \mathrm{x} \\
\text { Kelpak SL } 2.0 \mathrm{dm}^{3} \cdot \mathrm{ha}^{-1}\end{array}$ & 40.88 & 39.78 & 42.54 & 50.74 & 37.07 & 35.40 & 35,2 \\
\hline 4.Sencor 70 WG $1.0 \mathrm{~kg} \cdot \mathrm{ha}^{-1}$ & 42.79 & 41.04 & 46.13 & 50.37 & 38.17 & 41.42 & 43.32 \\
\hline $\begin{array}{l}\text { 5.Sencor } 70 \text { WG } 1.0 \mathrm{~kg} \cdot \mathrm{ha}^{-1} ; 2 \times \text { Asahi } \\
\text { SL } 1.0 \mathrm{dm}^{3} \cdot \mathrm{ha}^{-1}\end{array}$ & 44.71 & 42.81 & 47.44 & 51.67 & 40.15 & 43.13 & 44.98 \\
\hline Mean & 40.07 & 38.56 & 42.29 & 47.29 & 36.82 & 36.82 & - \\
\hline $\begin{array}{l}\mathrm{LSD}_{0.05} \text { for: } \\
\text { years } \\
\text { cultivars } \\
\text { weed control methods }\end{array}$ & & & & & & & $\begin{array}{l}2.22 \\
2.22 \\
2.05\end{array}$ \\
\hline
\end{tabular}


or Kelpak SL bio-stimulants, there was an increase in the yield of potato tubers compared to the control objects. In addition, Kelpak SL also significantly increased the large tubers fraction, at the expense of medium tubers. Additionally, Pytlarz-Kozicka and Zagórska [2013] obtained the highest total yield of tubers on objects, where the biological tuber seasoning was used.

\section{CONCLUSIONS}

1. The smallest dry weed mass determined in both research dates was obtained using the Harrier 295 ZC herbicide and the Kelpak SL growth bio-stimulant, while the largest on the control object.

2. The total yield of potato tubers depended on both the herbicides and bio-stimulants used and the varieties cultivated in the experiment.

3 . The weather conditions varied in particular years, considerably influencing the amount of air-dried matter of weeds and the yield of potatoes.

\section{Acknowledgements}

The results of the research carried out under the research theme No. 363/S/13 were financed from the science grant granted by the Ministry of Science and Higher Education.

\section{REFERENCES}

1. Anioł A., Bielecki S., Twardowski T. 2008. Genetically modified organisms - benefits and hazards for Poland. NAUKA, 1, 63-84. (in Polish)

2. Dobrzański A., Anyszka Z., Elkner K. 2008. Response of carrots to application of natural extracts from seaweed (Sargassum sp.). Algaminoplant and from leonardite - Humiplant. J. Res. App. Agric Eng., 53(3), 53-58.

3. Emitazi G., Nader A., Etemadifar Z. 2004. Effect of nitrogen fixing bacteria on growth of potato tubers. Advances in Food Sci., 26(2), 56-58.

4. Fernandez-Quintanilla C., Quadranti M., Kudsk P., Barberi P. 2008. Which future for weed science. Weed Res., 48, 297-301.

5. Golian J., Anyszka Z., Kohut M. 2014. The assessment of herbicides application with biostimulants and adjuvants in carrot (Daucus carota L.). Prog. Plant Prot./Post. Ochr. Roślin, 54(2), 167-173.

6. Gugała M., Zarzecka K., Sikorska A. 2014. The weed infestation and yielding of potato depending on the mechanical and chemical treatments. Fragm. Agron., 31(3), 50-57.

7. Kierzek R., Dubas M., Matysiak K. 2013. Wpływ łącznego stosowania biostymulatora Aminoplant z herbicydami na wielkość i jakość plonu buraka cukrowego. Prog. Plant Prot./ Post. Ochr. Roślin. 53(3), 621-626.

8. Kierzek R., Dubas M., Matysiak K. 2015. Wpływ łącznego stosowania biostymulatora Aminoplant $\mathrm{z}$ mieszaniną terbutyloazyny i bromoksynilu (Zeagran $340 \mathrm{SE}$ ) na efekt chwastobójczy oraz plonowanie kukurydzy. Prog. Plant Prot./ Post. Ochr. Roślin. 55 (2), 164-169.

9. Kołodziejczyk M. 2013. Wpływ warunków opadowo-termicznych na plonowanie średnio późnych i późnych odmian ziemniaka jadalnego. Ann. UMCS, Sect. E. Agricultura. Vol. LXVIII(3), 1-10.

10. Kositorna J., Smoliński M. 2008. Asahi SL biostymulator in protection of sugar beet from herbicide stress. p. 41-49. In: "Biostimulators in Modern Agriculture. Field Crops" (Z.T. Dąbrowski, ed.). Wieś Jutra, Warszawa, 118 ss.

11. Koziara W., Sulewska H., Panasiewicz K. 2006. Effect of resistance stimulator application to some agricultural crops J. Res. Appl. Agric. Eng., 51(2), 82-87.

12. Maciejewski T., Michalski T., Bartos-Spychała M. 2008. Effect of the application of biostimulator Asahi SL on the yield of potato tubers and their quality. In: Biostimulators in modern agriculture. Konf. 7-8 February, Warszawa. Part: Solanaceous crops. (Ed.) Dąbrowski Z. T., Wieś Jutra: 52-60.

13. Maciejewski T., Szukała J., Jarosz A. 2007. Influence of biostymulator Asahi SL i Atonik SL on qualitative tubers of potatoes. J. Res. Appl. Agric. Eng., 52(3), 109-112.

14. Matysiak K. 2010. Technologically and interventional. Wiadomości Rolnicze Polska 66(3), 6. (in Polish)

15. Matysiak K., Adamczewski K. 2010. Effect of plant growth and development regulator Moddus 250 EC, Kelpak SL, Algaminoplant, Humiplant and Yeald Plus on the yield and size of potato tubers. Ziemniak Polski, 1, 28-33. (in Polish)

16. Mystkowska I., Zarzecka K., Baranowska A., Gugała M. 2017. Weed infestation of potato cultivars depending on weed control methods and weather conditions. Acta Agroph., 24(1), 111-121.

17. Praczyk T., Skrzypczak G. 2011. The current state and directions of weed science development. Prog. Plant Prot./Post. Ochr. Roślin, 51(1), 354-363.

18. Pytlarz-Kozicka M., Zagórski P. 2013. Wpływ biologicznych zapraw na zdrowotność roślin i plonowanie ziemniaka. Prog. Plant Prot./Postępy w 
Ochronie Roślin. 53(2), 333-339.

19. Sawicka B., Barbaś P., Dąbek-Gad M. 2011. The problem of weed infestation in conditions of applying the growth bioregulators and foliar fertilization in potato cultivation. Nauka Przyr. Technol., 5(2), 1-12.

20. Sekutowski T., Badowski M. 2010. Wpływ zachwaszczenia, warunków meteorologicznych i ochrony herbicydowej na plon i poszczególne frakcje bulw ziemniaka. Prog. Plant Prot./ Post. Ochr. Roślin. 50(3), 1390-1394.

21. Trawczyński C. 2014. Wpływ biostymulatorów aminokwasowych - Tecamin - na plon i jakość ziemniaków. Ziemniak Polski 3, 29-34.

22. Trętowski J., Wójcik R. 1991. Methodology of agricultural experiments. Wyd. WSRP Siedlce, 500.

23. Wichrowska D. 2008. The effect of herbicides on the yield and structure of potato tubers cultivated in the Kujawsko-Pomorskie region. Ekol. Tech., 16(4), 141-144.

24. Wierzbicka A., Trawczyński C. 2016. Yields potential and level of their utilization by the potato cultivars registered in the years 2006-2015. Fragm. Agron., 33(4), 145-154.

25. Zarzecka K., Gugała M., Dołęga H. 2013. Regulation of weed infestation degree in potato with the use of herbicides. Biul. IHAR, 267, 113-119. 